\title{
Studi Analisis Pengaruh Filter Aktif Berbasis Fuzzy Logic Controller Untuk Mereduksi Harmonisa Akibat Beban Non Linier
}

\author{
G. A. M. Dwi Ade Saputra*, I Wayan Rinas, I Made Suartika \\ Program Studi Teknik Elektro, Fakultas Teknik, Universitas Udayana \\ Email: dwiadesaputra34@gmail.com
}

\begin{abstract}
Abstrak
Peralatan listrik yang dikatagorikan beban nonlinier akan menimbulkan harmonisa. Harmonisa merupakan distorsi periodik pada gelomang sinus yang dapat menyebabkan dampak negatif terhadap komponen peralatan elektronika. Salah satu cara meningkatkan kualitas daya adalah dengan mereduksi harmonisa menggunakan filter harmonisa. Pada penelitian ini dilakukan analisis pada sistem sebelum ditambah filter dan setelah ditambah filter aktif berbasis fuzzy logic controller. Penerapan metode fuzzy logic pada filter befungsi untuk mengurangi overswitching pada inverter sehingga dapat mencapai nilai THDi terendah. Hasil simulasi THDi saat kondisi eksisting pada phasa R, S, T; adalah sebesar 14\%, 17\%, 14\%. Saat kondisi filter aktif tanpa kontrol, presentase THDi pada phasa R sebesar 6\%, phasa S sebesar $6 \%$, phasa T sebesar 4\%. Pada kondisi filter aktif berbasis fuzzy logic controller peresentase THDi pada phasa R, S, T; adalah 0,9\%, 0,9, 1\%. Berdasarkan hasil simulasi diketahui bahwa filter aktif berbasis fuzzy logic controller mampu mereduksi distorsi harmonisa hingga nilai terendah, sehingga penggunaan fuzzy logic pada filter aktif dapat digunakan dalam proses filterisasi harmonisa pada sistem kelistrikan.
\end{abstract}

Kata kunci: Harmonisa, THDi, Fuzzy Logic Controller

\begin{abstract}
Electrical equipment categorized as the nonlinear load will cause harmonics. Harmonic is a periodic distortion of the sine wave that can cause a negative impact on electronic equipment components. One way to improve power quality is to reduce harmonics using harmonic filters. In this study, an analysis of the system was carried out before adding a filter and after adding an active filter based on a fuzzy logic controller. The application of the fuzzy logic method on filters functions to reduce over switching in the inverter so that it can reach the lowest THDi value. THDi simulation results when the existing conditions are in phase R, S, T; at 14\%, 17\%, 14\%. When the active filter condition is without control, the THDi percentage at the $R$ phase is $6 \%$, the $S$ phase is $6 \%$, the $T$ phase is $4 \%$. In the active filter conditions based on the fuzzy logic controller the percentage of THDi in phase $R, S, T$; is $0.9 \%, 0.9,1 \%$. Based on the simulation results introduced in the active filter based fuzzy logic controller is able to reduce harmonic distortion to the lowest value, so the use of fuzzy logic in active filters can be used in the harmonic filtering process in the electrical system.
\end{abstract}

Keywords : Harmonic, THDi, Fuzzy Logic Controller

\section{PENDAHULUAN}

Kampus Fakultas Teknik Universitas Udayana Jalan P.B. Sudirman Denpasar merupakan tempat publik yang memiliki banyak peralatan elektronik. Sebagian

besar peralatan elektronik dikatagorikan sebagai beban nonlinier sehingga mengakibatkan munculnya permasalahan harmonisa pada sistem kelistrikannya. 
Meningkatnya penggunaan peralatan elektronika yang bersifat beban nonlinier dapat memicu timbulnya distorsi gelombang sinus yang disebabkan oleh penumpangan frekuensi kelipatan bilangan integer dari frekunesi fundamentalnya atau dikenal dengan istilah harmonisa. Harmonisa yang timbul memiliki dampak buruk bagi sistem kelistrikan [1].

Sistem ketenagalistrikan Fakultas Teknik Universitas Udayana Jalan P. B Sudirman disuplai oleh dua buah transformator distribusi $20 \mathrm{kV} / 380 \mathrm{~V}$ yang salah satunya memiliki kapasitas daya 100 kVA yang mengalirkan daya listrik ke sebuah MDP Fakultas Teknik yang mensuplai kebutuhan beban di gedung $B$, C, D dan E pada sistem ketenagalistrikannya.

Berdasarkan data hasil pengukuran Total Harmonic Current Distortion (THDi) dan dengan membandingkan pada standar IEEE 519-2014 maka nilai THDi pada MDP yang menyuplai beban gedung $B, C, D$ dan E yaitu pada phasa $R=9,8 \%$ phasa $S=$ $11,0 \%$ phasa $T=7,5 \%$. Data hasil pengukuran THDi yang diperoleh di MDP Fakultas Teknik Universitas Udayana Jalan P. B Sudirman masih belum sesuai dengan batas standar IEEE 519-2014 yang telah ditentukan yaitu sebesar $8 \%$ yang sebelumnya didapat melalui perhitungan $\mathrm{SC}_{\text {Ratio }}$ [2].

Usaha dalam meredam harmonisa yang berlebih dapat dilakukan dengan cara mengoperasikan filter aktif pada sistem kelistrikannya. Filter aktif bekerja dengan cara membentuk arus kompensasi yang berlawanan arah dengan arus harmonisa yang ditimbulkan akibat beban nonlinier. Pengembangan teknik filtering pada harmonisa sudah sangat maju salah satunya menggunakan metode PID namun metode ini masih terlalu sederhana pada sistem kontrolnya [3].

Sehingga pada penelitian ini dirancang filter aktif berbasis fuzzy logic controller untuk mereduksi harmonisa akibat beban nonlinier yang terdapat pada sistem kelistrikannya, dimana fuzzy logic memiliki banyak variabel yang dapat diatur sehingga dapat berpengaruh pada arus kompensasi yang akan dihasilkan.

\section{KAJIAN PUSTAKA}

2.1. Harmonisa

Harmonisa adalah deretan gelombang arus ataupun tegangan yang memiliki frekuensi kelipatan bilangan bulat dari frekuensi fundamentalnya. Pada dasarnya gelombang arus ataupun tegangan yang berasal dari sumber tiga phasa merupakan gelombang sinusoidal murni. Namun pengoperasian dari beban listrik nonlinier yang menghasilkan gelombang integer dari frekuensi fundamentalnya menyebabkan gelombang dasar akan tertumpang dan mengalami bentuk gelombang non sinusoidal akibat distrosi gelombang pada arus maupun tegangan [1] [4].

\subsection{Sumber Harmonisa}

Terjadinya gangguan harmonisa pada sistem tenaga listrik disebabkan oleh banyaknya pemakian peralatan - peralatan yang merupakan beban berjenis nonlinier, seperti : inverter, converter, penerangan, dan lain sebagainya [5-6].

\subsection{Standar Harmonisa}

Standar harmonisa dibuat untuk menentukan batasan kandungan harmonisa yang diperbolehkan dalam sistem kelistrikan yang telah diatur dalam standar IEEE 519-2014.

a. Standar THD tegangan

Standar THD tegangan berdasarkan IEEE 519-2014 dapat dilihat pada Tabel 1.

Tabel 1. Standar THD tegangan [7]

\begin{tabular}{|c|c|c|}
\hline $\begin{array}{l}\text { Bus Voltage (V) at } \\
P C C\end{array}$ & $\begin{array}{l}\text { Individual Harmonic } \\
(\%)\end{array}$ & $\begin{array}{l}\text { Total Harmonic } \\
\text { Distortion (\%) }\end{array}$ \\
\hline $\mathrm{V} \leq 1 \mathrm{KV}$ & 5.0 & 8.0 \\
\hline $1 \mathrm{kV}<\mathrm{V}<69 \mathrm{Kv}$ & 3.0 & 5.0 \\
\hline $69 \mathrm{kV}<\mathrm{V}<161 \mathrm{kV}$ & 1.5 & 2.5 \\
\hline $161 \mathrm{kV}<\mathrm{V}$ & 1.0 & 1.5 \\
\hline
\end{tabular}

b. Standar THD arus 
Standar THD arus berdasarkan IEEE 519-2014 dapat dilihat pada Tabel 2.

Tabel 2. Standar THD arus [7]

\begin{tabular}{|c|c|c|c|c|c|c|}
\hline \multicolumn{7}{|c|}{ Maximum Harmonic Current Distortion in Percent of $\mathrm{I}_{L}$} \\
\hline \multicolumn{7}{|c|}{ Individual Harmonic Order (odd harmonic ${ }^{a, b}$} \\
\hline Isc I $\mathrm{I}$ & $3 \leq \mathrm{h} \leq$ & $11 \leq \mathrm{h} \leq$ & $17 \leq \mathrm{h} \leq$ & $23 \leq \mathrm{h} \leq$ & $35 \leq \mathrm{h}$ & $\mathrm{THD}$ \\
& 11 & 17 & 23 & 35 & $\leq 50$ & $(\%)$ \\
\hline$<20 \mathrm{c}$ & 4.0 & 2.0 & 1.5 & 0.6 & 0.3 & 5.0 \\
\hline $20<50$ & 7.0 & 3.5 & 2.5 & 1.0 & 0.5 & 8.0 \\
\hline $50<100$ & 10.0 & 4.5 & 4.0 & 1.5 & 0.7 & 12.0 \\
\hline $100<1000$ & 12.0 & 5.5 & 5.0 & 2.0 & 1.0 & 15.0 \\
\hline$>1000$ & 15.0 & 7.0 & 6.0 & 2.5 & 1.4 & 20.0 \\
\hline
\end{tabular}

Untuk menentukan batas THDi pada suatu sistem kelistrikan dapat dilakukan dengan menggunakan perhitungan Short Circuit Ratio ( $\left.\mathrm{SC}_{\text {rasio }}\right)$ seperti pada Persamaan 1.

$S C_{\text {Ratio }}=\frac{I_{S C}}{I_{L}}$

Nilai arus hubung singkat $\left(I_{S C}\right)$ tiga phasa dapat dihitung dengan menggunakan persamaan 2 .

$I_{S C}=\frac{s \times 100}{\%[\times \sqrt{3} \times V s}$

Keterangan :

$I_{\text {sc }}$ adalah nilai arus hubung singkat

$I_{L}$ adalah arus beban

$S$ adalah daya semu transformator (kVA)

$V_{s}$ adalah tegangan sisi sekunder transformator $(\mathrm{kV})$

$Z(\%)$ adalah persentase impedansi

Sedangkan nilai arus beban penuh $\left(I_{L}\right)$ tiga phasa dapat dihitung dengan menggunakan Persamaan 3.

$\mathrm{I}_{\mathrm{L}}=\frac{P}{P F \sqrt{3} \times V_{p}}$

Keterangan :

$\mathrm{P}$ adalah Daya aktif $(\mathrm{kW})$

$P F$ adalah Power Factor $(\cos \varphi)$

$\mathrm{V}_{\mathrm{p}}$ adalah tegangan hasil pengukuran

\subsection{Filter Aktif}

Filter aktif merupakan filter yang banyak digunakan dalam mereduksi harmonisa pada sistem ketenagalistrikan. Filter aktif sering digunakan karena memiliki topologi yang tidak sulit dan fleksibel [3].

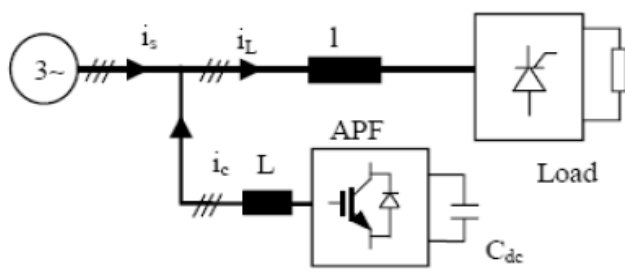

Gambar 1. Konfigurasi Filter Aktif [8]

Filter aktif menggunakan komponen elektronika daya seperti $\mathrm{R}, \mathrm{C}$ dan Op-Amp untuk menghasilkan komponen arus spesifik yang berguna untuk mereduksi komponen arus harmonisa yang dihasilkan oleh beban nonlinier [8-9].

\subsection{Fuzzy Logic Controller}

Sistem fuzzy adalah sistem yang dibangun berdasarkan aturan lingustik sederhana untuk menetukan perintah pada sistem kontrol. Perintah yang diberikan dibangun berdasarkan definisi, cara kerja, dan deskripsi yang jelas berdasarkan pemahaman pada teori fuzzy logic controller. Dasar teori pada fuzzy logic controller membahas mengenai konsep dasar himpunan pada fuzzy logic controller, yang mencakup mengenai himpunan, operasi logika dan hukum - hukum pada himpunan fuzzy logic controller [10].

\section{METODE PENELITIAN}

Penelitian dilakukan di gedung Fakultas Teknik Universitas Udayana Jalan P.B. Sudirman Denpasar. Data yang diperoleh merupakan data hasil pengukuran langsung pada MDP Fakultas Teknik. Data yang digunakan antara lain seperti tegangan, arus, faktor daya, daya aktif, THDi pada sistem kelistrikan dan data spesifikasi transformator dari Trafindo. Selanjutnya dilakukan simulasi pemodelan pada kondisi eksisting, filter aktif tanpa kontrol dan filter aktif berbasis fuzzy logic controller yang dilakukan simulasi pada setiap phasanya. Hasil simulasi dibandingkan dengan batas THDi yang telah ditentukan. Hasil simulasi 
yang telah dilakukan akan dibandingkan dengan batas THDi yang telah ditentukan oleh IEEE 519-2014 serta melihat nilai penurunan THDi.

\section{HASIL DAN PEMBAHASAN}

4.1. Simulasi Tanpa Menggunakan Filter Aktif (Kondisi Eksisting)

Penelitian ini menggunakan perangkat lunak Simulink MATLAB untuk simulasi THD pada pemodelan sistem kelistrikan Fakultas Teknik Universitas Udayana Sudirman. Pada sistem awal ini disimulasikan tanpa menggunakan filter aktif pada sistem kelistrikannya. Model simulasi dari sistem kelistrikan Fakultas Teknik Universitas Udayana dapat dilihat pada gambar 3.

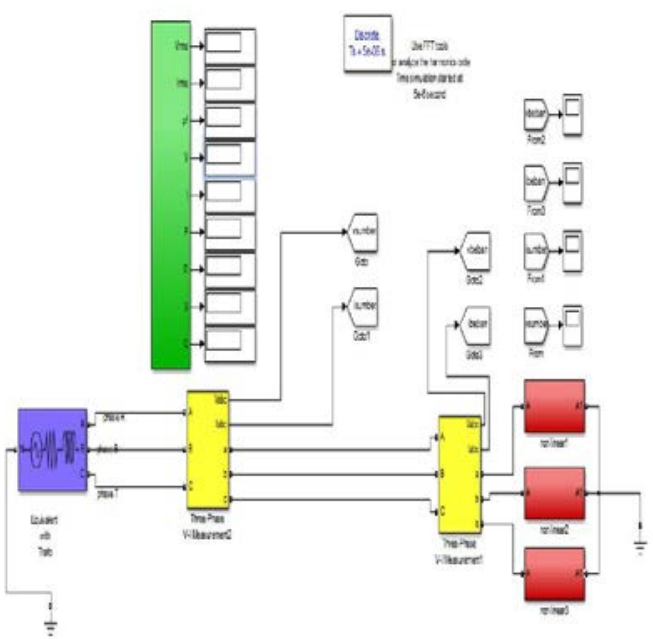

Gambar 3. Model Simulasi Sistem Kelistrikan Sebelum Terpasang Filter

Dari model simulasi pada gambar 3 maka dapat diketahui nilai THDi sistem kelistrikan dalam kondisi eksisting sebagai berikut.

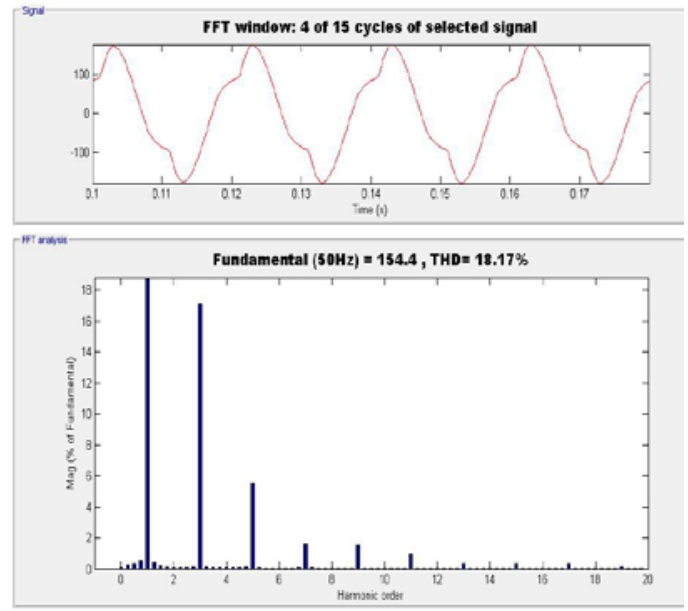

Gambar 4. THDi Phasa R Kondisi Eksisting

Gambar 4 merupakan hasil simulasi THDi pada phasa R saat kondisi eksisting, dari hasil simulasi diketahui kandungan THDi sebesar 18,17\% Dengan cara yang sama yaitu mengguanakan bantuan FFT dalam menampilkan hasil simulasi pada phasa $\mathrm{R}$ maka hasil dari phasa $\mathrm{S}$ dan $\mathrm{T}$ adalah $18,30 \%$ dan $14,17 \%$.

4.2. Simulasi Menggunakan Filter Aktif Tanpa Fuzzy Logic Controller

Pada simulasi sistem kelistrikan mengoperasikan filter aktif tanpa fuzzy logic controller menyebabkan penurunan nilai THDi yang dapat dilihat pada gambar 5 .
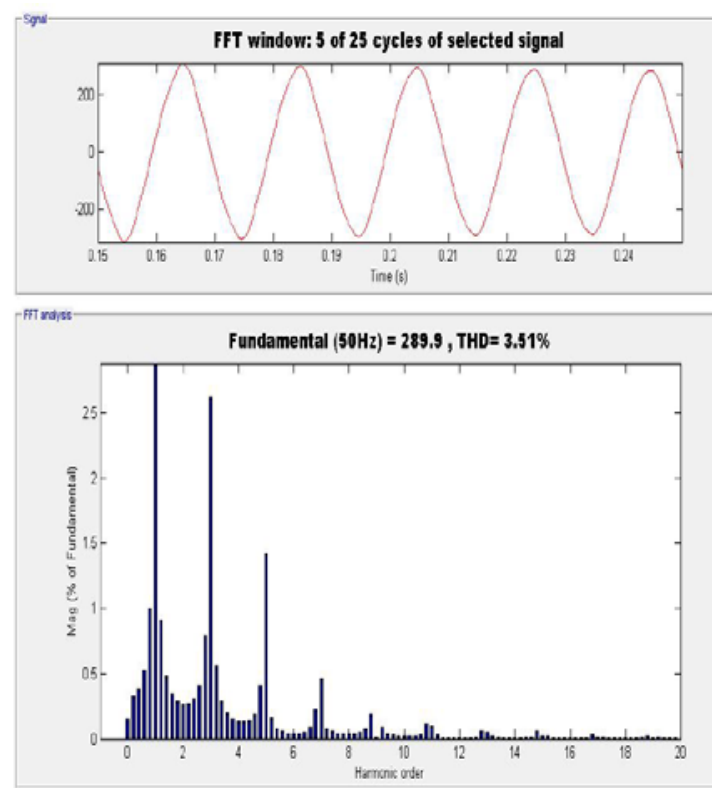

Gambar 5. Hasil Simulasi Phasa R pada kondisi Filter Aktif Tanpa Kontrol 
Gambar 5. merupakan hasil simulasi THDi pada phasa $\mathrm{R}$ saat kondisi telah dioperasikan filter aktif tanpa fuzzy logic controller. Dengan cara yang sama maka dari hasil simulasi diketahui kandungan THDi phasa R, S, T adalah 3,51\%, 3,59\% dan 3,83\%.

\subsection{Simulasi Menggunakan Filter Aktif} Berbasis Fuzzy Logic Controller

Berikut merupakan rangkaian filter aktif berbasis fuzzy logic controller dengan skema FLC 7 fungsi keanggotaan.

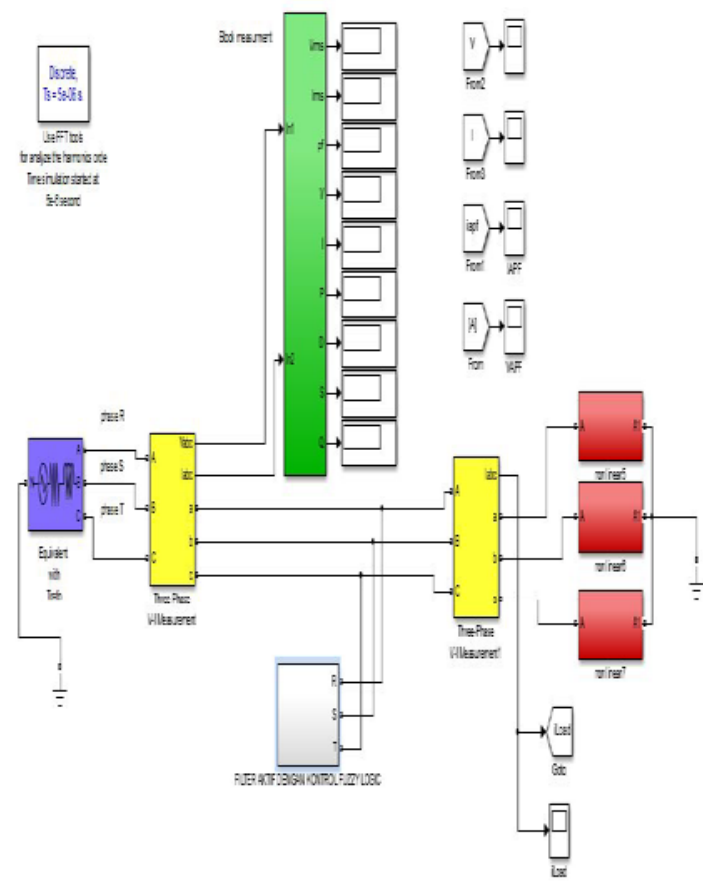

Gambar 6. Desain model Simulink filter aktif berbasis fuzzy logic controller

Gambar 6 merupakan rangkaian implementasi fuzzy logic controller pada filter aktif. Fuzzy logic berfungsi menerima input error dari arus refrensi yang dihasilkan di dalam proses sub current compesation pada filter aktif.

Pada penelitian ini menggunakan konfigurasi fuzzy logic controller dengan 7 membership function sehingga dapat dilihat pada gambar dibawah ini.

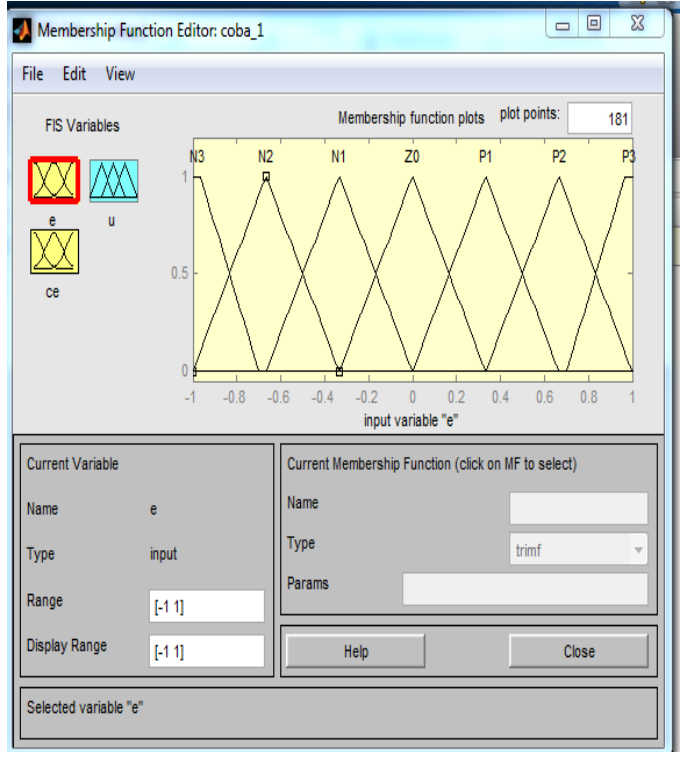

Gambar 7. Membership Function

Setelah membership function terbentuk maka selanjutnya dapat ditentukan rule base functionnya sebagai berikut :

Tabel 3. Rule Base Function $7 \times 7$

\begin{tabular}{|c|c|c|c|c|c|c|c|}
\hline \multirow{2}{*}{ Dherroln } & \multicolumn{7}{|c|}{ Error } \\
\hline & $\mathrm{N} 3$ & $\mathrm{~N} 2$ & $\mathrm{Nl}$ & Z0 & $\mathrm{Pl}$ & P2 & P3 \\
\hline $\mathrm{N} 3$ & $\mathrm{~N} 3$ & $\mathrm{~N} 3$ & $\mathrm{~N} 3$ & $\mathrm{~N} 3$ & $\mathrm{~N} 2$ & $\mathrm{Nl}$ & Z0 \\
\hline $\mathrm{N} 2$ & $\mathrm{~N} 3$ & $\mathrm{~N} 3$ & $\mathrm{~N} 3$ & $\mathrm{~N} 2$ & $\mathrm{Nl}$ & Z0 & $\mathrm{Pl}$ \\
\hline $\mathrm{Nl}$ & $\mathrm{N} 3$ & $\mathrm{~N} 3$ & $\mathrm{~N} 2$ & $\mathrm{Nl}$ & $\mathrm{ZO}$ & $\mathrm{Pl}$ & P2 \\
\hline $\mathrm{ZO}$ & $\mathrm{N} 3$ & $\mathrm{~N} 2$ & $\mathrm{Nl}$ & $Z 0$ & $\mathrm{Pl}$ & $\mathrm{P2}$ & P3 \\
\hline $\mathrm{Pl}$ & $\mathrm{N} 2$ & $\mathrm{Nl}$ & $\mathrm{ZO}$ & $\mathrm{Pl}$ & P2 & P3 & P3 \\
\hline P2 & $\mathrm{Nl}$ & Z0 & $\mathrm{Pl}$ & P2 & P3 & P3 & P3 \\
\hline P3 & 20 & $\mathrm{Pl}$ & P2 & $\mathrm{P3}$ & $\mathrm{P3}$ & P3 & P3 \\
\hline
\end{tabular}

Hasil simulasi dari pemodelan filter aktif berbasis fuzzy logic controller yang didapat menggunakan bantuan FFT pada panel MDP setelah pemasangan dapat dilihat pada gambar 8 . 


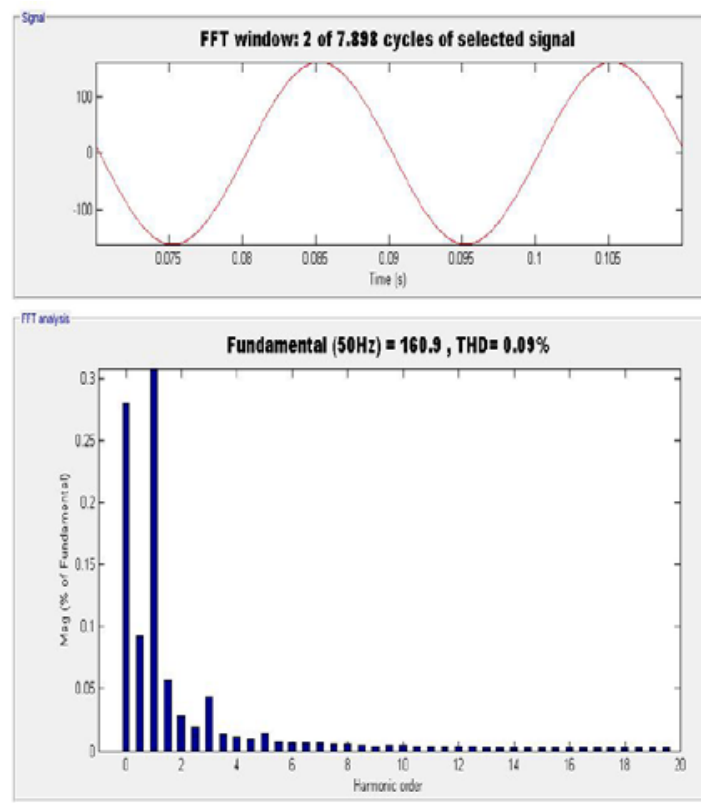

Gambar 8. Hasil THDi Phasa R saat kondisi terpasang filter aktif berbasis Fuzzy Logic Controller

Gambar 8 merupakan hasil simulasi THDi pada phasa $\mathrm{R}$ setelah terpasangnya filter aktif shunt berbasis fuzzy logic controller. Pada phasa $\mathrm{R}$ gambar bagian atas menampilkan gelombang sinusoidal yang lebih baik sehingga dapat dikatakan kandungan THDi yang berada pada sistem sudah mengalami penurunan atau telah tereduksi dikarenakan terpasangnya filter aktif shunt berbasis fuzzy logic. Kandungan THDi yang terpada pada phasa $\mathrm{R}$ adalah $0,09 \%$. Hasil simulasi tiap phasa dapat dilihat pada tabel 4 .

Tabel 4. Nilai Tiap Phasa Setelah Pemasangan Filter Aktif Berbasis Fuzzy Logic Controller

\begin{tabular}{|c|c|c|c|l|}
\hline Kondisi & Phasa & $\begin{array}{c}\text { THD arus } \\
\text { Hasil } \\
\text { Simulasi (\%) }\end{array}$ & $\begin{array}{c}\text { Standar IEEE 519- } \\
\mathbf{2 0 1 4}(\%)\end{array}$ & Keterangan \\
\hline $\begin{array}{c}\text { Filter Aktif } \\
\text { Berbasis } \\
\text { Fuzzy logic } \\
\text { controller }\end{array}$ & $\mathrm{R}$ & 0,09 & 8,0 & $\begin{array}{l}\text { Sesuai } \\
\text { Standar }\end{array}$ \\
\cline { 2 - 5 } & $\mathrm{S}$ & 0,25 & 8,0 & $\begin{array}{l}\text { Sesuai } \\
\text { Standar }\end{array}$ \\
\cline { 2 - 5 } & $\mathrm{T}$ & 0,14 & 8,0 & $\begin{array}{l}\text { Sesuai } \\
\text { Standar }\end{array}$ \\
\hline
\end{tabular}

Dari tabel 4 diketahui penurunan THDi yang sangat baik dari setiap phasanya. Nilai THDi yang terdapat pada phasa $\mathrm{R}$ adalah sebesar $0,09 \%$ yang mana merupakan sudah berada dibawah nilai standar yang telah ditetapkan oleh IEEE 519-2014 yaitu sebesar 8\%. Pada phasa S dan $T$ masing-masing phasa juga mengalami penurunan THDi yang sangat baik dimana pada phasa $S$ memiliki nilai $0,25 \%$ dan phasa T memiliki nilai $0,14 \%$.

\subsection{Anasilis Nilai THDi pada setiap kondisi Simulasi}

Berdasarkan hasil ketiga simulasi yang telah dilakukan maka selanjutnya dapat dilakukan analisa THDi pada masingmasing hasil simulasi. Perbandingan hasil THDi pada setiap simulasi dapat dilihat pada tabel 5.

Tabel 5. Perbandingan hasil simulasi THDi pada setiap kondisi simulasi

\begin{tabular}{|c|c|c|c|c|c|c|}
\hline \multirow[t]{2}{*}{ Tempet } & \multirow[t]{2}{*}{ Phasa } & $\begin{array}{c}\text { Tanpa Filter } \\
\text { Aktif/Kondisi } \\
\text { Eksisting }\end{array}$ & $\begin{array}{c}\text { Filter } \\
\text { aktif } \\
\text { tanpa } \\
\text { kontrol }\end{array}$ & $\begin{array}{l}\text { Filter aktif } \\
\text { berbasis } \\
\text { fuzzy logic } \\
\text { controller }\end{array}$ & $\begin{array}{c}\text { IEEE } \\
\text { Standar } \\
519- \\
2014\end{array}$ & KET \\
\hline & & THD $\operatorname{arus}(\%)$ & $\begin{array}{l}\text { THD } \\
\text { arus } \\
(\%)\end{array}$ & $\begin{array}{c}\text { THD arus } \\
(\%)\end{array}$ & $\begin{array}{c}\text { THD arus } \\
(\%)\end{array}$ & \\
\hline \multirow{3}{*}{$\begin{array}{c}\text { MDP } \\
\text { Fakullas } \\
\text { Teknik } \\
\text { Sudirman }\end{array}$} & $\mathrm{R}$ & 18,17 & 3.51 & 0,09 & 8 & $\begin{array}{l}\text { Memenui } \\
\text { Standar }\end{array}$ \\
\hline & S & 18,38 & 3.59 & 0,25 & 8 & $\begin{array}{l}\text { Memenuil } \\
\text { Standar }\end{array}$ \\
\hline & $\mathrm{T}$ & 14,17 & 3.83 & 0,14 & 8 & $\begin{array}{l}\text { Memenui } \\
\text { Standar }\end{array}$ \\
\hline
\end{tabular}

Tabel 5 menampilkan hasil simulasi saat sistem belum terpasang filter aktif atau dalam keadaan eksisiting nilai THDi yang terkandung adalah pada phasa $\mathrm{R}=18,17$ $\%$, phasa $\mathrm{S}=18,38 \%$ dan phasa $\mathrm{T}=$ 14,17 . Saat sistem dalam keadaan sudah terpasang filter aktif tapi belum berbasis pada sistem kontrol fuzzy, nilai THDi adalah pada phasa $\mathrm{R}=3,51 \%$, phasa $\mathrm{S}=3,59 \%$ dan phasa $\mathrm{T} 3,83 \%$. Saat sistem disimulasikan sudah terpasang filter aktif berbasis fuzzy logic controller maka kondisi nilai THDi adalah pada phasa $\mathrm{R}=0,09 \%$, phasa $S=0,25 \%$ dan phasa $\mathrm{T}=0,14 \%$. Sehingga standar IEEE 519 - 2014 sebesar $8 \%$ sudah terpenuhi karena nilai telah berada dibawah batas maksumum dari THDi yang telah ditentukan. Seperti yang dapat dilihat pada gambar 9 . 


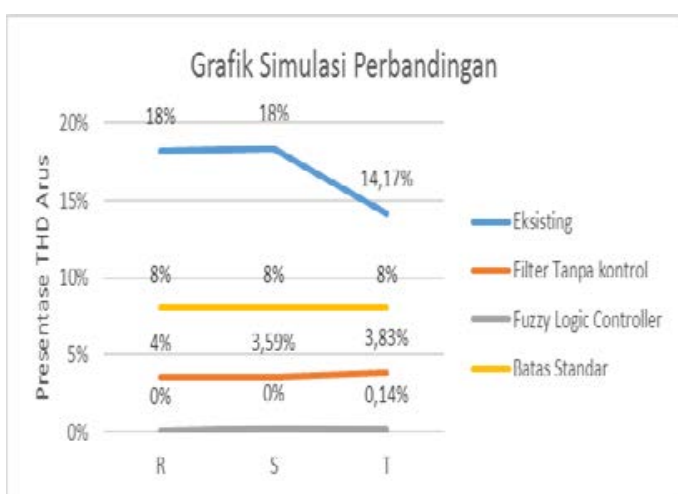

Gambar 9. Hasil Simulasi Eksisting, Filter Aktif dan Filter Aktif berbasis Fuzzy Logic Controller

Berdasarkan bentuk grafik pada gambar 9, menyatakan bawah nilai THDI pada sistem memiliki batas standar (blok warna kuning) yaitu 8\%. Grafik filter aktif berbasis fuzzy logic controller (berwarna abu-abu) merupakan grafik yang menghasilkan nilai THDi terendah, dengan kata lain dapat memberikan kompensasi THDi yang lebih baik.

\section{KESIMPULAN}

Berdasarkan hasil simulasi dan analisis yang telah dilakukan pada kondisi eksisting persentase THDi pada Phasa $\mathrm{R}$ sebesar 18,17\%, Phasa S sebesar 18,38 $\%$, Phasa T sebesar $14,17 \%$. Saat kondisi sistem kelistrikan telah terpasang filter aktif tanpa kontrol, persentase THDi pada masing-masing phasa mengalami penurunan, pada phasa $\mathrm{R}$ menjadi $3,51 \%$, Phasa S menjadi 3,59 \%, dan Phasa T menjadi $3,83 \%$. Simulasi ketiga pada kondisi sistem telah terpasang filter aktif berbasis fuzzy logic controller presentase nilai THDi pada phasa $\mathrm{R}$ sebesar 0,09\%, phasa $S$ sebesar $0,25 \%$, dan phasa $T$ sebesar $0,14 \%$. Dibandingkan dengan ketiga simulasi yang telah dilakukan, kondisi sistem dengan terpasang filter aktif berbasis fuzzy logic controller merupakan yang terbaik karena mampu mereduksi THDi hingga $\pm 98 \%$ dari kondisi eksisting pada masing-masing phasanya sehingga pengopersian filter aktif berbasis fuzzy logic controller memiliki nilai yang paling baik. Pengoperasian filter aktif berbasis fuzzy logic controller pada sistem kelistrikan Fakultas Teknik Udayana Jalan P.B Sudirman menyebabkan penurunan nilai THDi, sehingga nilai THDi yang terkandung pada sistem telah memenuhi standar IEEE 519 Tahun 2014.

\section{DAFTAR PUSTAKA}

[1] Dugan, R.C., McGranaghan, M.F, Santoso, S., Beaty, H.W, Electrical Power System Quality-Second Edition. The McGraw-Hill. 2004.

[2] Janardana, IGN, Effect Of Value Of Resistance Announcement to THD In Electrical System Faculty of Engineering University Udayana Denpasar". Journal Of Electrical, Electronics, and Informatics, $\mathrm{Vol} 2$ No.1

[3] Pahlevi, AB. 2017. " Reduksi Harmonisa Pada Motor Sinkron 3 Phasa Menggunakan Filter Aktif Shunt Berbasis Fuzzy Logic". Yogyakarta : CITEE 2017.

[4] Ferracci, Ph. 2001. Power Quality. Cahier Technique Merlin Gerin no: 199

[5] Rosa. Francisco C. De La. 2006. Harmonics and Power Systems. Distribution Control Systems, Inc.; USA

[6] Ekastawa Putra, IW., Rinas, IW., Putu Arya Mertasana. 2014. "Kajian dan Analisa Distorsi Harmonisa di Hotel Amankila". Jimbaran : Jurusan Teknik Elektro, Universitas Udayana

[7] IEEE Standards Association. 519 2014. IEEE Recommended Practice and Requirements for Harmonic Control in Electric Power Systems. New York; IEEE Press; 2014.

[8] Izhar. M. et al. "Performance for Passive and Active Power Filter in Reducing Harmonics in the Distribution System", National Power \& Energi Conference (PECon) 2004, IEEE Proceedings, Kuala Lumpur, Malaysia, pp. 104-108, 2004.

[9] Purwajaya, IW., Rinas, IW., Arta Wijaya, IW. 2013. "Analisis Perbandingan Penggunaan Filter Pasif, Filter Aktif, Dan Filter Hybrid Shunt 
Untuk Meredam Gangguan

Resonansi Harmonisa". Jurusan

Teknik Elektro, Fakultas Teknik,

Universitas Udayana, E-Journal

SPEKTRUM, Vol. 4.
[10] Kusumadewi, S, 2006, Aplikasi Logika Fuzzy Untuk Pendukung Keputusan, Graha IImu, Yogyakarta. 